\title{
PRODUKTIVITAS TENAGA KERJA \\ SEBELUM DAN SESUDAH PERUBAHAN VOLUME PADA KONTRAK DI PEMBANGUNAN PROYEK RUSUN SURABAYA
}

\author{
Bagus Dwipurwanto' ${ }^{1}$ I Gede Agus Widyadana², Januar Budiman³
}

\begin{abstract}
ABSTRAK: Perubahan dalam kontrak sering terjadi pada proyek konstruksi karena suatu proyek konstruksi selalu mengalami beberapa perubahan. Perubahan yang paling banyak terjadi pada tahap pelaksanaan konstruksi adalah perubahan volume. Perubahan volume bisa menyebabkan bertambahnya biaya, waktu penyelesaian pekerjaan dan dapat mempengaruhi produktivitas pekerja. berdasarkan uraian tersebut maka penelitian dilakukan untuk menganalisa apakah terdapat perbedaan produktivitas sebelum dan sesudah perubahan. Penelitian ini dilakukan pada dua proyek rusun Surabaya yang merupakan proyek pemerintah. Berdasarkan hasil analisa maka didapatkan kesimpulan bahwa terdapat peningkatan produktivitas setelah adanya perubahan volume kontrak. Peningkatan ini terjadi karena adanya batas waktu pelaksanaan kontrak pada proyek pemerintah. Sehingga menuntut pihak kontraktor dapat memacu dan meningkatkan produktivitasnya.
\end{abstract}

Kata kunci: perubahan volume kontrak, produktivitas dan tenaga kerja.

ABSTRACT: Changes in the contract often occur on a construction project sincea construction project oftenhas some changes. The changes that commonly occur during the implementation phase of construction is the change in volume. Changes in volume can lead to increase cost, time of completion of work and affect worker productivity. The description is based on the research conducted to analyze whether there are differences in productivity before and after the change. This research was conducted in two towers project Surabaya which are government project. Based on the analysis it is concluded that productivity is after the change in contract volume. This occurs because contracts on government projects set tied contract deadline, So the contractor can stimulate and improve productivity.

Keyword: contract change, impacts, productivity and labor.

\section{PENDAHULUAN}

Perubahan dalam kontrak sering terjadi pada proyek konstruksi karena suatu proyek konstruksi selalu mengalami beberapa perubahan. Perubahan yang paling banyak terjadi pada tahap pelaksanaan konstruksi adalah perubahan volume. Perubahan volume bisa menyebabkan bertambahnya biaya dan waktu penyelesaian pekerjaan. Akibat perubahan volume dapat mempengaruhi produktivitas pekerja. Sering terjadi perubahan volume pada kontrak dan keterlambatan penyelesaian kontrak akibat kurang optimumnya dalam memaksimalkan produktivitas pekerja pada proyek pembangunan rusun.

\footnotetext{
${ }^{1}$ Mahasiswa Program Studi Magister Teknik Sipil Universitas Kristen Petra, m01513001@john.petra.ac.id

${ }^{2}$ Dosen Program Studi Magister Teknik sipil Universitas Kristen Petra, gede@petra.gede.ac.id

${ }^{3}$ Dosen Program Studi Magister Teknik sipil Universitas Kristen Petra, januar@petra.ac.id
} 
Sehingga, perlu diketahui berapakah produktivitas pekerja pada pada saat sebelum dan sesudah perubahan volume pada kontrak pada proyek pembangunan rusun Surabaya agar proyek dapat berjalan lebih efektif dan efisien.

Penelitian serupa sudah pernah dilakukan oleh Thomas dan Napolitan (1995). Penelitian terdahulu belum melakukan analisa perhitungan produktivitas secara kuantitatif, oleh sebab itu dalam penelitian ini akan dilakukan perhitungan produktivitas tenaga kerja secara kuantitatif berkaitan dengan perubahan proyek.

\section{PERUMUSAN MASALAH}

Berdasarkan dari latar belakang yang telah diuraikan, maka permasalahan yang akan dibahas pada penelitian ini adalah.

1) Bagaimana produktivitas sebelum dan sesudah perubahan volume pada kontrak diproyek rusun A Surabaya dan proyek rusun B Surabaya?

2) Apakah produktivitas pekerja pada proyek rusun A Surabaya sama dengan produktivitas proyek rusun B Surabaya?

\section{TUJUAN PENELITIAN}

Berdasarkan diatas terdapat latar belakang dan perumusan masalah yang telah dirumuskan, maka tujuan penelitian ini adalah untuk mengindentifikasi dan mengetahui produktivitas sebelum dan sesudah perubahan volume pada kontrak di proyek rusun A Surabaya dan proyek rusun B Surabaya dan juga melihat perbedaan produktivitas di kedua proyek tersebut.

\section{MANFAAT PENELITIAN}

Penelitian ini diharapkan bermanfaat dalam menunjang penerapan ilmu pengetahuan ketekniksipilan terutama dalam bidang bangunan tingkat tinggi dan ilmu manajemen konstruksi pada khususnya dalam hal memanajemen tenaga kerja, dapat menjadi informasi pembanding bagi penelitian yang akan dilakukan dimasa mendatang dan juga bermanfaat bagi peneliti sendiri agar dapat mengindentifikasi dan mengetahui perubahan volume pada kontrak terhadap produktivitas pekerja pada proyek rusun Surabaya.

\section{RUANG LINGKUP PENELITIAN}

1) Penelitian dilakukan pada proyek rusun Surabaya

2) Penelitian dilakukan untuk pekerjaan struktur, arsitektural, mekanikal dan elektrikal.

3) Penelitian tidak membahas tentang faktor-faktor yang mempengaruhi produktivitas.

4) Penelitian berdasarkan data kuantitatif dari laporan akhir kontraktor Rusun.

\section{LANDASAN TEORI}

\subsection{Rumah Susun (RUSUN)}

Rumah susun atau disingkat rusun, kerap dikonotasikan sebagai apartemen versi sederhana , walaupun sebenarnya apartemen bertingkat sendiri bisa dikategorikan sebagai rumah susun. Rusun menjadi jawaban atas terbatasnya lahan untuk pemukiman di daerah perkotaan.

\subsection{Perubahan Kontrak}

Perubahan dalam kontrak sering terjadi pada proyek konstruksi karena suatu proyek konstruksi selalu mengalami beberapa perubahan. Beberapa jenis perubahan kontrak sudah diatur dalam Perpres 70 tahun 2012 Pasal 87 dan Perpres 70 tahun 2012 Pasal 52. 


\subsection{Produktivitas Tenaga Kerja}

Produktivitas dapat didefinisikan dalam banyak cara. Dalam konstruksi produktivitas biasanya diartikan produktivitas tenaga kerja, yang dimaksud adalah unit kerja ditempatkan atau diproduksi per man-jam. Dengan demikian, jumlah item yang terpasang berhubungan dengan masing - masing unit kerja selesai. Kemudian dapat didefinisikan sebagai rasio terpasang untuk waktu tertentu. Hal ini tergantung pada metode yang digunakan untuk mengukur produktivitas dan sejauh mana faktor yang mempengaruhi itu (Shehata, M.E. dan El-Gohary, M.E., 2011).

Daily productivity merupakan produktivitas harian yang dihasilkan pekerja di lapangan. Daily productivity sangat penting untuk mempelajari pola fluktuasi produktivitas kelompok pekerja di lapangan.

$$
\text { Daily Productivity }=\frac{\text { Daily work hour }}{\text { Daily Quantity }}
$$

Baseline productivity menunjukkan nilai produktivitas standar yang menjadi target kontaktor dalam bagian dari suatu proyek.

1) Menentukan $10 \%$ dari total hari pengamatan yang selanjutnya disebut sebagai baseline subset ( $n$ ).

2) Banyaknya baseline subset tidak boleh kurang dari 5 hari pengamatan, jika kurang dari 5 hari pengamatan maka diambil minimal 5 hari pengamatan.

3) Dari keseluruhan hari pengamatan itu, diambil output harian yang terbesar sebesar $n$ buah hari pengamatan.

4) Tentukan daily productivity untuk masing-masing hari pengamatan tersebut.

5) Nilai produktifitas tersebut kemudian diurutkan mulai yang terbesar ke yang terkecil, nilai tengah dari $n$ nilai produktifitas harian tersebut merupakan baseline productivity.

Total productivity adalah produktivitas total dari suatu pekerjaan selama hari pengamatan. Produktivitas ini digunakan untuk melihat produktivitas pekerja rata-rata selama hari pengamatan.

$$
\text { Total Productivity }=\frac{\text { Total } \text { work hour }}{\text { Total Quantity }}
$$

Cumulative productivity merupakan kumpulan seluruh work hours pekerjaan dibagi jumlah total yang terpasang.

$$
\text { Cumulative Productivity }=\frac{\text { Cumulative work hour }}{\text { Cumulative Quantity }}
$$

Productivity waste merupakan suatu parameter yang digunakan untuk menunjukkan performance produktivitas tenaga kerja (Thomas, H.R., 2000).

$$
\text { Productivity Waste }=\frac{\text { Baseline productivity }- \text { Cumulative productivity }}{\text { Baseline productivity }}
$$

\subsection{Analisis $T$ Student's Test}

Uji t ini digunakan untuk menguji nilai 2 buah rata-rata sampel dimana terdapat dua kelompok sampel. Dengan dua buah kelompok ini, akan dicari apakah kedua kelompok tersebut berbeda atau tidak. Nilai $t$ dapat dicari dengan rumus sebagai berikut: 


$$
\mathrm{t}=\frac{\left(\overline{\mathrm{X}_{\mathrm{A}}}-\overline{\mathrm{X}_{\mathrm{B}}}\right)-\delta_{0}}{\mathrm{~S}}
$$

dimana $\overline{\mathrm{X}_{\mathrm{A}}}$ merupakan rata-rata kelompok $\mathrm{A}, \overline{\mathrm{X}_{\mathrm{B}}}$ merupakan rata-rata kelompok $\mathrm{B}, \delta_{0}=$ $\left(\mu_{A}-\mu_{B}\right)$ yang merupakan hipotesis populasi yang akan diuji berupa selisih antara rata-rata kelompok $\mathrm{A}$ dan kelompok $\mathrm{B}$ dan $\mathrm{S}$ merupakan deviasi standar.

Uji t ini juga dapat digunakan untuk menguji kecocokan atas perbedaan pada suatu perlakuan tertentu didalam sekelompok objek penelitian. Sehingga, perhitungan didasarkan pada selisih antara nilai pengukuran sebelum perlakuan (pre test) dengan nilai pengukuran sesudah perlakuan (post test). Nilai t dapat dapat dihitung dengan rumus sebagai berikut.

$$
t=\frac{\bar{D}-\mu_{0}}{s_{d} / \sqrt{n}}
$$

dimana $\mu_{0}$ merupakan ipotesis populasi berupa rata-rata dari selisih pengukuran, $\overline{\mathrm{D}}$ merupakan rata-rata dari selisih pengukuran sampel $S_{d}$ merupakan deviasi standar dari selisih pengukuran sampel dan n merupakan jumlah sampel (Irianto, 2010).

\section{ALUR PENELITIAN}

Alur penelitian yang akan dilakukan dapat dilihat pada Gambar 1 sebagai berikut.

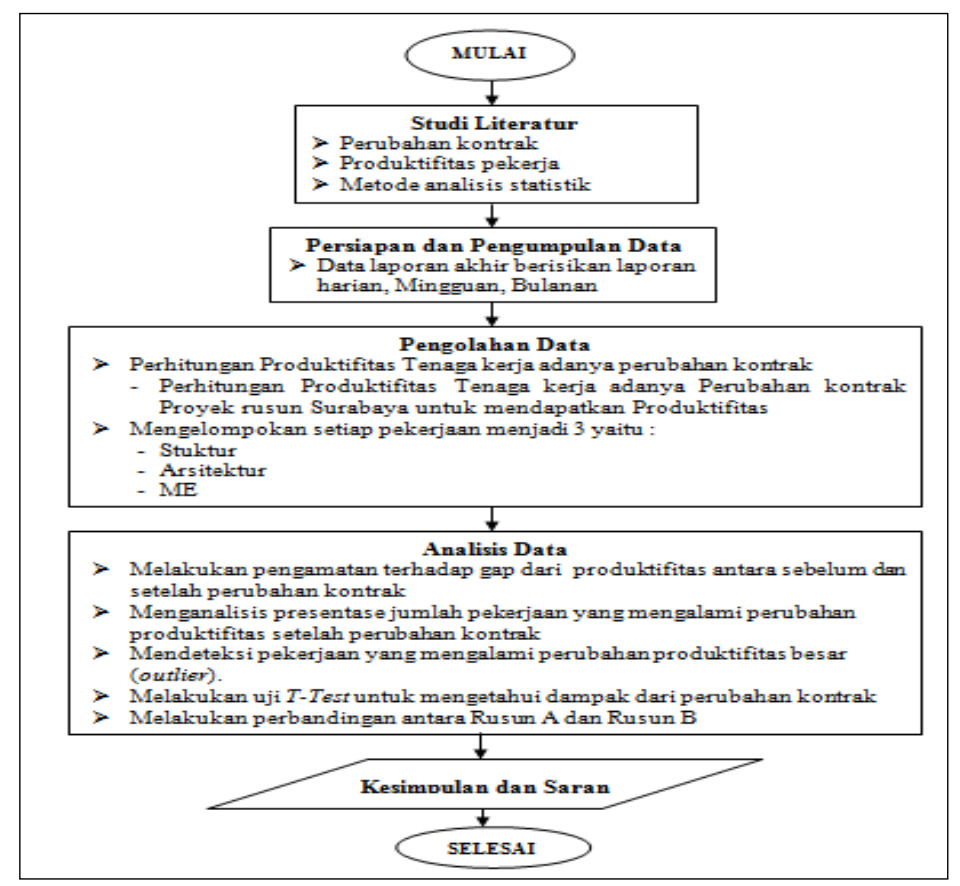

Gambar 1. Alur Penelitian

\section{ANALISIS DATA}

Data yang telah terkumpul, kemudian diolah untuk mendapatkan nilai produktifitas dengan adanya perubahan kontrak proyek pada pembangunan proyek Rusun A dan Rusun B Surabaya. Untuk mempermudah proses perhitungan perlu dilakukan pengelompokan setiap 
pekerjaan menjadi 3 yaitu pengolahan data stuktur, arsitektur dan ME (Mekanikal dan Elektrikal).

\subsection{Produktivitas Pekerja pada Proyek Rusun A Surabaya}

Berdasarkan Gambar 2 dapat dilihat bahwa untuk pekerjaan struktur, terdapat $74,03 \%$ pekerjaan yang mengalami peningkatan, terdapat 22,08\% pekerjaan yang mengalami penurunan dan terdapat $3,90 \%$ pekerjaan struktur yang tidak mengalami perubahan produktivitas. Lalu untuk pekerjaan arsitektur, dapat dilihat bahwa terdapat $58,33 \%$ pekerjaan yang mengalami peningkatan dan terdapat $41,67 \%$ pekerjaan yang mengalami penurunan produktivitas setelah adanya perubahan volume pada kontrak.

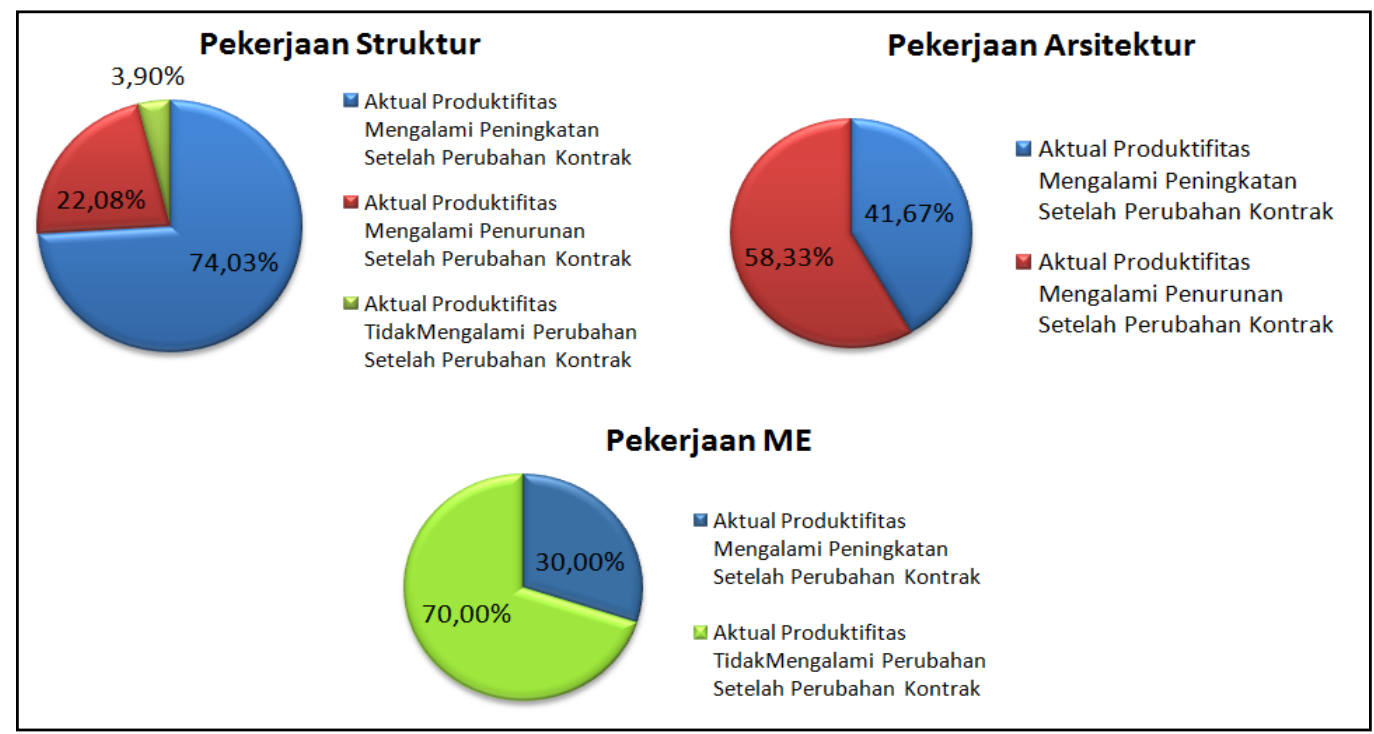

Gambar 2. Perubahan Produktivitas Setelah Adanya Perubahan Volume pada Kontrak pada Proyek Rusun A Surabaya

Sedangkan untuk pekerjaan ME, dapat dilihat pada Gambar 2 bahwa presentase pekerjaan yang mengalami peningkatan hanya sebesar $30 \%$ dan pekerjaan yang tidak mengalami perubahan setelah adanya perubahan volume pada kontrak adalah sebesar $70 \%$.

Tabel 1. Paired T-Test antara Sebelum dan Setelah Adanya Perubahan Volume dalam Kontrak pada Proyek Rusun A Surabaya

\begin{tabular}{|c|c|c|c|c|c|c|c|c|c|}
\hline \multirow{3}{*}{\multicolumn{2}{|c|}{$\begin{array}{l}\text { Paired T Test RUSUN A } \\
\text { (SEBELUM, VS SETELAH) }\end{array}$}} & \multicolumn{8}{|c|}{ Pair Differences } \\
\hline & & \multirow[t]{2}{*}{ Mean } & \multirow[t]{2}{*}{$\begin{array}{l}\text { Std. } \\
\text { Dev }\end{array}$} & \multirow{2}{*}{$\begin{array}{l}\text { Std. } \\
\text { Error } \\
\text { Mean }\end{array}$} & \multicolumn{2}{|c|}{$\begin{array}{l}\text { 95\% Confidence } \\
\text { Interval of the } \\
\text { Difference }\end{array}$} & \multirow[t]{2}{*}{$t$} & \multirow[t]{2}{*}{$d f$} & \multirow[t]{2}{*}{$\begin{array}{c}\text { Sig. } \\
\text { (2-tailed) }\end{array}$} \\
\hline & & & & & Lower & Upper & & & \\
\hline Struktur & $\begin{array}{c}\text { REALISASI } \\
\text { (SEBELUM - SETELAH) }\end{array}$ & $-0,41$ & 1,07 & 0,13 & $-0,68$ & $-0,14$ & $-3,08$ & 63 & $\underline{0,00}$ \\
\hline Arsitektur & $\begin{array}{c}\text { REALISASI } \\
\text { (SEBELUM - SETELAH) }\end{array}$ & $-0,05$ & 0,48 & 0,10 & $-0,27$ & 016 & $-0,51$ & 21 & $\underline{0,62}$ \\
\hline
\end{tabular}

Pada Tabel 1 dapat diketahui bahwa rata-rata dari selisih produktivitas sebelum dengan setelah perubahan untuk pekerjaan struktur dan arsitektur bernilai negatif yang berarti bahwa secara keseluruhan produktivitas pekerja cenderung mengalami peningkatan setelah adanya 
perubahan volume pada kontrak. Untuk mengetahui signifikansi dari peningkatan tersebut, maka dilakukan T-Test yang menghasilkan nilai $p$-value. Dapat diketahui untuk pekerjaan struktur, nilai p-value kurang dari dari 0,05 (taraf kesalahan) yang berarti bahwa peningkatan produktivitas yang terjadi cukup signifikan pada taraf kepercayaan 95\% dan sebaliknya untuk pekerjaan arsitektur, bahwa nilai p-value lebih dari dari 0,05 (taraf kesalahan) yang berarti bahwa peningkatan produktivitas yang terjadi tidaklah signifikan pada taraf kepercayaan $95 \%$. Sedangkan untuk pekerjaan ME, T-Test tidak dilakukan karena jumlah data pekerjaan yang sedikit, sehingga pengamatan cukup dilakukan melalui grafik seperti pada Gambar 2.

\subsection{Produktivitas Pekerja pada Proyek Rusun B Surabaya}

Berdasarkan Gambar 3 dapat dilihat bahwa untuk pekerjaan struktur, terdapat $72,73 \%$ pekerjaan yang mengalami peningkatan, terdapat $27,27 \%$ pekerjaan yang mengalami penurunan produktivitas. Lalu untuk pekerjaan arsitektur, dapat dilihat bahwa terdapat $31,25 \%$ pekerjaan yang mengalami peningkatan dan terdapat $68,75 \%$ pekerjaan yang mengalami penurunan produktivitas setelah adanya perubahan volume pada kontrak.

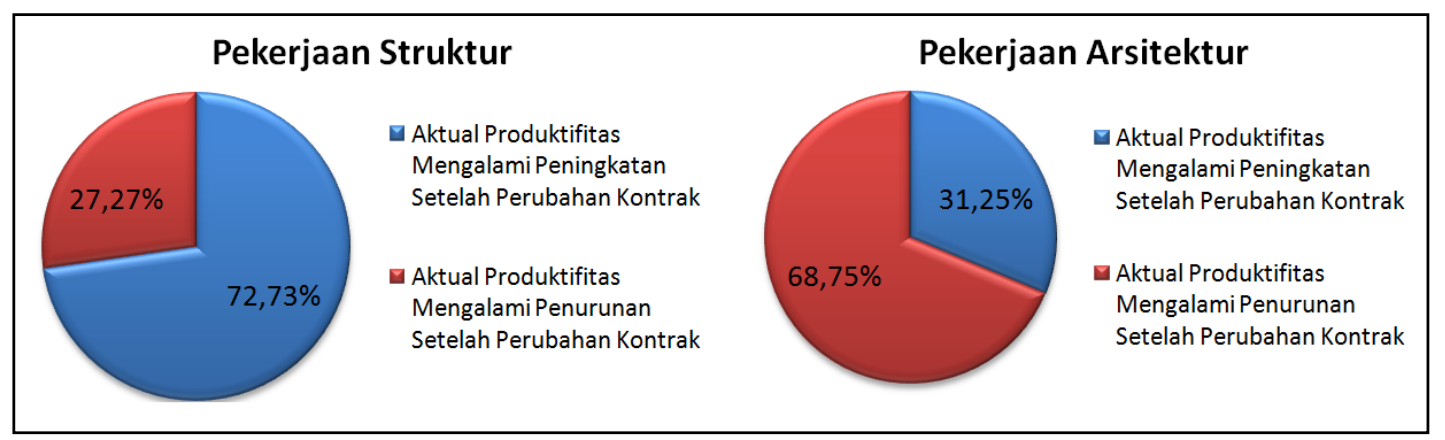

Gambar 3. Perubahan Produktivitas setelah Adanya Perubahan Volume dalam Kontrak pada Proyek Rusun B Surabaya

Sedangkan untuk pekerjaan ME, grafik tidak ditampilkan karena produktifitas pekerja pada setiap pekerjaan ME adalah sama baik sebelum maupun setelah perubahan volume kontrak yaitu 1.

Tabel 2. Paired T-Test antara Sebelum dan Setelah Adanya Perubahan Volume dalam Kontrak pada Proyek Rusun B Surabaya

\begin{tabular}{|c|c|c|c|c|c|c|c|c|c|}
\hline \multirow{3}{*}{\multicolumn{2}{|c|}{$\begin{array}{c}\text { Paired T Test RUSUN B } \\
\text { (SEBELUM, VS SETELAH) }\end{array}$}} & \multicolumn{8}{|c|}{ Pair Differences } \\
\hline & & \multirow[t]{2}{*}{ Mean } & \multirow[t]{2}{*}{$\begin{array}{l}\text { Std. } \\
\text { Dev }\end{array}$} & \multirow[t]{2}{*}{$\begin{array}{l}\text { Std. } \\
\text { Error } \\
\text { Mean }\end{array}$} & \multicolumn{2}{|c|}{$\begin{array}{c}95 \% \\
\text { Confidence } \\
\text { Interval of the } \\
\text { Difference }\end{array}$} & \multirow[t]{2}{*}{$t$} & \multirow[t]{2}{*}{$d f$} & \multirow[t]{2}{*}{$\begin{array}{c}\text { Sig. } \\
\text { (2-tailed) }\end{array}$} \\
\hline & & & & & Lower & Upper & & & \\
\hline Struktur & $\begin{array}{c}\text { REALISASI } \\
\text { (SEBELUM - SETELAH) }\end{array}$ & $-0,31$ & 0,81 & 0,11 & $-0,52$ & $-0,10$ & $-2,87$ & 56 & $\underline{0,01}$ \\
\hline Arsitektur & $\begin{array}{c}\text { REALISASI } \\
\text { (SEBELUM - SETELAH) }\end{array}$ & 0,09 & 0,26 & 0,06 & $-0,04$ & 0,23 & 1,47 & 15 & $\underline{0,16}$ \\
\hline
\end{tabular}

Pada Tabel 1 dapat diketahui bahwa rata-rata dari selisih produktivitas sebelum dengan setelah perubahan untuk pekerjaan struktur bernilai negatif yang berarti bahwa secara 
keseluruhan (dilihat dari rata-ratanya) produktivitas pekerja cenderung mengalami peningkatan setelah adanya perubahan volume pada kontrak, namun sebaliknya untuk pekerjaan arsitektur yang cenderung mengalami penurunan. Untuk mengetahui signifikansi dari perubahan tersebut, maka dilakukan T-Test yang menghasilkan nilai $p$-value. Dapat diketahui untuk pekerjaan struktur, nilai $p$-value kurang dari 0,05 (taraf kesalahan) yang berarti bahwa peningkatan produktivitas yang terjadi cukup signifikan pada taraf kepercayaan 95\% dan sebaliknya untuk pekerjaan arsitektur, bahwa nilai $p$-value lebih dari dari 0,05 (taraf kesalahan) yang berarti bahwa penurunan produktivitas yang terjadi tidaklah signifikan pada taraf kepercayaan $95 \%$.

Sedangkan untuk pekerjaan ME, T-Test tidak dilakukan karena jumlah data pekerjaan yang sedikit dan nilai produktifitas pekerja pada setiap pekerjaan ME adalah sama baik sebelum maupun setelah perubahan volume kontrak yaitu 1.

\subsection{Perbandingan Produktivitas Pekerja pada Proyek Rusun A dan Rusun B Surabaya}

Perbandingan presentase pekerjaan yang mengalami perubahan produktivitas seperti yang telah dibahas sebelumnya ditampilkan pada Gambar 4 berikut ini.

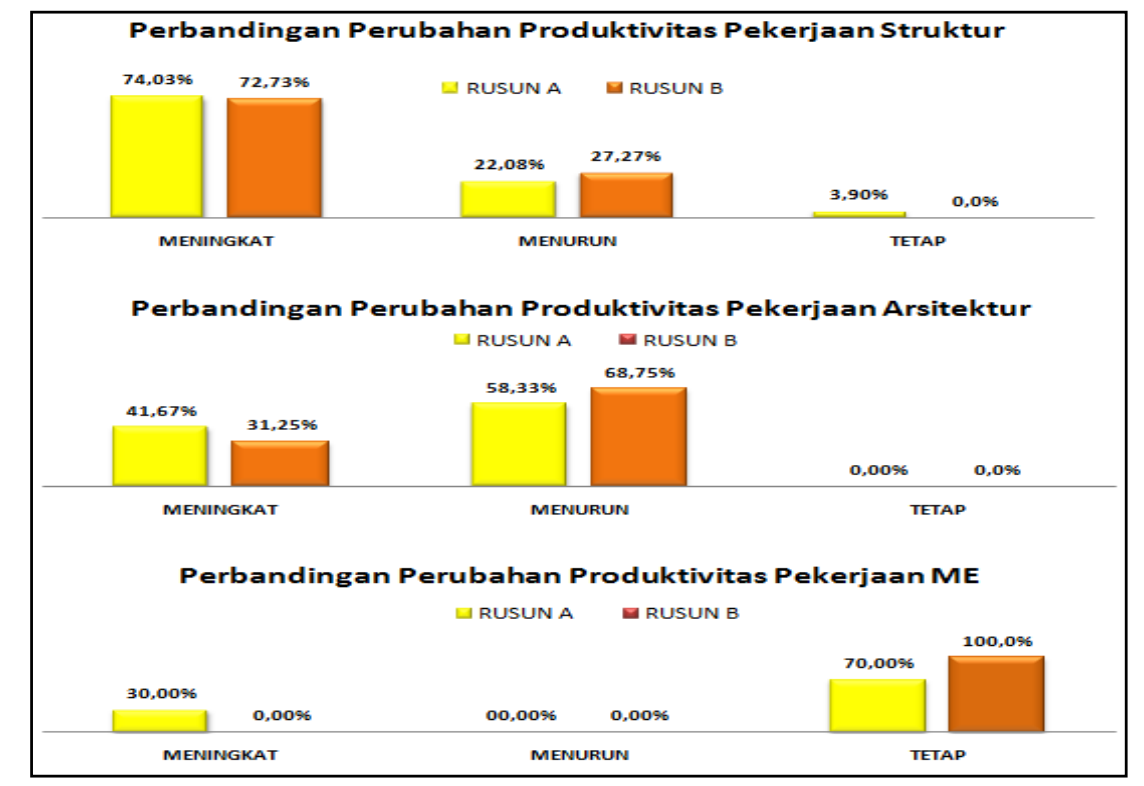

Gambar 4. Perbandingan Perubahan Produktivitas Setelah Adanya Perubahan Volume pada Kontrak antara Proyek Rusun A dan Rusun B Surabaya

Dapat dilihat pada Gambar 4 bahwa presentase pekerjaan yang mengalami perubahan produktivitas antara Rusun A dan Rusun B hampir serupa, yaitu produktivitas pekerja untuk pekerjaan struktur dominan mengalami peningkatan, produktivitas pekerja untuk pekerjaan arsitektur dominan mengalami penurunan dan produktivitas pekerja untuk pekerjaan struktur dominan tidak mengalami perubahan setelah adanya perubahan volume pada kontrak. Untuk memperjelas perbedaan produktivitas antara Rusun A dan Rusun B, maka dilakukan T-test dengan hasil seperti pada Tabel 3 berikut ini. 
Tabel 3. Independent T-Test antara Produktivitas Pekerja Rusun A dan Rusun B Surabaya

\begin{tabular}{|c|c|c|c|c|c|c|}
\hline \multirow{2}{*}{ Pekerjaan } & \multirow{2}{*}{$\begin{array}{c}\text { Independent T-Test } \\
\text { (RUSUN A VS RUSUN B) }\end{array}$} & \multicolumn{2}{|c|}{$\begin{array}{l}\text { Levene's Test for } \\
\text { Equality of Variances }\end{array}$} & \multicolumn{3}{|c|}{ t-test for Equality of Means } \\
\hline & & $F$ & Sig. & $t$ & $d f$ & $\begin{array}{l}\text { Sig. (2- } \\
\text { tailed) }\end{array}$ \\
\hline \multirow{2}{*}{ Struktur } & $\begin{array}{c}\text { PRODUKTIVITAS } \\
\text { SEBELUM PERUBAHAN }\end{array}$ & 0,444 & 0,506 & 0,297 & 118,245 & $\underline{0,767}$ \\
\hline & $\begin{array}{c}\text { PRODUKTIVITAS } \\
\text { SETELAH PERUBAHAN }\end{array}$ & 5,206 & 0,024 & 1,297 & 141,000 & $\underline{0,197}$ \\
\hline \multirow[b]{2}{*}{ Arsitektur } & $\begin{array}{c}\text { PRODUKTIVITAS } \\
\text { SEBELUM PERUBAHAN }\end{array}$ & 1,034 & 0,316 & $-0,458$ & 34,009 & $\underline{0,650}$ \\
\hline & $\begin{array}{c}\text { PRODUKTIVITAS } \\
\text { SETELAH PERUBAHAN }\end{array}$ & 6,344 & 0,016 & 1,589 & 38,000 & $\underline{0,120}$ \\
\hline
\end{tabular}

Hasil T-test pada tabel 3 menunjukkan nilai $p$-value yang lebih besar dari 0,05 (taraf kesalahan) untuk setiap pekerjaan baik sebelum maupun setelah perubahan volume kontrak yang bahwa pada taraf kepercayaan $95 \%$ tidak terdapat perbedaan produktivitas pekerja yang signifikan antara proyek Rusun A dan Rusun B.

\section{KESIMPULAN}

Perubahan volume pada kontrak yang terjadi pada proyek Rusun A dan Rusun B tidak memberikan yang signifikan terhadap aktual produktivitas pekerja pada untuk pekerjaan arsitektur dan ME, tetapi perubahan volume pada kontrak memberikan perubahan yang cukup signifikan dimana produktivitas pekerja pada pekerjaan struktur meningkat.

Sedangkan perbandingan perubahan produktivitas pada proyek Rusun A dan Rusun B tidak berbeda signifikan dimana produktivitas pekerja untuk pekerjaan struktur dominan mengalami peningkatan, produktivitas pekerja untuk pekerjaan arsitektur dominan mengalami penurunan dan produktivitas pekerja untuk pekerjaan struktur dominan tidak mengalami perubahan setelah adanya perubahan volume pada kontrak.

\section{DAFTAR REFERENSI}

Irianto, Agus (2010). Statistik : Konsep Dasar, Aplikasi dan Pengembangannya. Kencana Prenada Media Group, Jakarta.

Shehata, M.E. dan El-Gohary, M.E. (2011). "Toward Improving Construction Labor Productivity and Project Performance." Alexandria Engineering Joumal, 50, 321-330.

Thomas, H. R., and Napolitan, C. L. (1995). "Quantitative Effect of Construction Changes on Labor Productivity." Journal of Construction Engineering and Management, 121(3),290296, Pennsylvania.

Thomas, H.R.(2000). Principle of Construction Labor Productivity Meassurement and Processing. Pennsylvania Transportation Institute Pennysylvania State, Pennsylvania. 